DOI https://doi.org/10.30525/978-9934-26-039-1-33

\title{
ВИТОКИ СИРІТСТВА В ОПОВІДАННЯХ Б. ПРУСА
}

\author{
Співачук В. O. \\ кандидат філологічних наук, \\ доиент кафедри іноземних мов \\ Хмельницького начіонального університету \\ м. Хмельницький, Украӥна
}

У кінці XIX ст. польська література мала значну кількість творів для дитячого читання. У 50-х pp. професор 3. Швейковський скерував наукове зацікавлення своїх учнів у сторону Великопольщі, результатом якого були перші дослідження життя і творчості Б. Пруса. У вступних статтях до творів письменника Олена Цибенько неодноразово акцентує увагу на наявності в них дитячої проблематики.

3-посеред науковців, які займаються дослідженням цього феномену, варто виокремити компаративне дослідження I. Спатар (оповідання Е. Ожешко, О. Маковея та І. Франка), О. Баган (романи Б. Пруса та I. Франка ), І. Ковальської (мала проза Б. Пруса і М. Коцюбинського).

Тема сирітства як соціального лиха ХІХ століття є однією з провідних у творчості Б. Пруса. Бідність, голод, жорстокість оточення - умови, за яких доводилося зростати тогочасним сиротам.

Б. Прус у своїх творах висвітлюючи соціально-педагогічні аспекти сирітства, має значний інтерес до сиріт, як соціальної проблеми, в його творах чітко прослідковується певна система соціально-педагогічних поглядів. Зневірений у суспільних порядках, Б. Прус вбачав краще майбутне у вихованні та розвитку моральної та чесної особистості. Тому і писав про дітей, керуючись потребою змінити і покращити умови їхнього життя, праці, освіти, виховання. Майстер слова оспівав красу дитячої душі, чисті та високі поривання своїх маленьких героїв.

Головною темою ранньої творчості Б. Пруса було зображення суспільної кривди. Дитинство в оповіданнях письменника не $є$ ідилією. Як зазначає І. Ковальська: «Це повністю виокремлений етап екзистенції. Світ дорослих, занурених у власні справи, не дає жодної опори малим героям» [1, с. 32]. Вони самотні та беззахисні. Б. Прус показує процес переходу від дитинства до дорослого життя шляхом подолання труднощів (наприклад смерті батьків чи друзів). Цей перехід не здійснюється свідомо і сплановано. Герой переживає розпач, робить безліч помилок. Так, наприклад, Казик Лєснєвський, головний герой 
«Гріхів дитинства», ступаючи на стежку дорослості, викликає гнів батька і сміх дам. Оповідач Пруса володіє знаннями про світ, дивиться на речі очима своїх героїв.

У дитячій прозі Болеслава Пруса можна виділити багато автобіографічних моментів. Письменник рано втратив батьків i виховувався в основному своєю тіткою. Можливо, зображення убогого, важкого і сумного дитинства («Сирітська доля», «Гріхи дитинства») $\epsilon$ спогадами власних дитячих років.

В оповіданні «Гріхи дитинства» (1883р.), головним героєм i оповідачем якого $\epsilon$ малий хлопець Казик Лєснєвський, син уповноваженого графині (оскільки в епоху, коли Казик народився «... всі неодмінно носили який-небудь титул або хоча б прізвисько, якими наділяли іноді без достатніх підстав» [2, с. 221]), який переживає своє перше почуття кохання до Льоні, дочки власниці палацу. Прус описує щасливі дитячі роки сільського хлопчика, його шкільні пригоди, дружбу з бідним і хворим однокласником, намагання наблизитися до захоплюючого його світу Льоні, капризної і зіпсутої дівчинки. Почуття вини й, одночасно, розчарування від пізнання ментальності і моральності «вищих» кіл суспільства призводить до того, що Казик без жалю залишає разом із батьком село, де вчинив свої, іронічно окреслені письменником, гріхи дитинства.

В оповіданні головну увагу Б. Прус приділяє не подіям, а психологічному портрету постаті Казика (прототипом якого міг бути сам письменник), а також інших героїв твору: Льоні, батька, слуг, Валека... Автор не коментує події, а намагається у жартівливій формі донести до читача найпотаємніші думки, які його хвилюють. Польський письменник заглиблюється у світ дитинства не лише бідного хлопчика, а й багатої Льоні.

Казик Лєснєвський зростав без матері, з батьком в нього відносини не складалися. Він ріс бешкетником i шибайголовою. Лише смерть однокласника Юзека вразила його і він почав шукати душевного тепла. Налагодив відносини з рідними і почав піклуватися про маленького Валека, який теж ріс сиротою, але без батька.

Здавалося би, при матері Валек мав би рости в любові і теплі, піклуванні, в той час, як Казик не бачив батьківської турботи. Але кожен 3 них зростав як «хиже пташеня, покинуте батьками» [2, с. 221]. I напевне, відчувши цю спорідненість, Казек і почав наглядати за Валеком. Вони, «не маючи друзів» [2, с. 222] товаришували з природою, знали «у парку кожен мурашник, у полі - кожну хом'якову нірку, кожне кротовиння у саду» [2, с. 222], а також «усі пташині гнізда, усі дупла, де 
жили більчата» [2, с. 222]. I Казек, і Валек були добрими й чуйними хлоп'ятами не зважаючи на те, що не бачили батьківської чи материнської любові.

Не бачив материнської любові і маленький хлопчик-сирота в оповіданні «Міхалко» $(1880$ р.). Б. Прус 3 глибокою симпатією i співчуттям передає умови життя героя, його мрії і прагнення: «Як ось у цього зайця, що скакав зараз через рейки, так і у нього, селянського сироти, будинок був в чистому полі, а комора - де бог пошле» [2, с. 370].

За порадою інженера він вирішує поїхати до Варшави в пошуках кращого життя. Але приказка «Краще там, де нас немає» не завжди $є$ правильною. Письменник передає психологічний стан Міхалка, коли той покидає село: «... сів спокійно, як йому було наказано. Але надто вже нудно було у нього на серці, і він почав читати молитву. Ах, як би йому хотілося повернутися в своє село, зліплене з соломи та глини, туди - в тишу боліт ... Та нема чого. Хоч і називали його «дурним», він все ж розумів, що в інших місцях менше мруть від голоду і легше знайти нічліг, ніж у них в селі. $\mathrm{O}$, в інших місцях і хліб біліший, і на м'ясо можна хоч подивитися, і будинків там більше, і люди не такі бідні, як у них» [2, с. 371].

Б. Прус показує боротьбу однієї людини 3 жорстоким світом несправедливості. Його герой самотній, покинутий усіма, розчарований у житті. I здається, кому він потрібен?: «Він перестав тривожитися про завтрашній день і насолоджувався нинішнім. А завтра ... завтра що бог дасть!» [2, с. 384].

Однак у відповідальний момент Міхалко виявляє мужність і відвагу. Він рятує Снджея з-під завалин будинку (не зважаючи на те, що був «... переляканий, можливо, більше за інших» [2, с. 386]). Але «він нібито відчував всю біль пораненого, його страх і відчай, але ... здавалось йому, що 3 усієї товщини саме він зобов'язаний врятувати цю людину, яка прийшла сюди $з$ села на заробітки.» [2, с. 386] Не чекаючи подяки, маленький герой діє за покликом серця. Йому ще не притаманне користолюбство, він не очікує винагороди, подяки за свої вчинки.

Оповідання «Антек» (1881р.) Б. Пруса значно відрізняється від інших дитячих творів польського письменника. Автор зобразив долю талановитої дитини, яка прагне розвиватися, поглиблювати свої знання, але реалії життя села 70-х рр. XIX ст. не дають їй такої можливості.

В основі оповідання - доля сільського хлопчика Антка. Він відрізняється від ровесників своєю вразливістю, недитячими поглядами на світ. Його не цікавить господарство. Він захоплюється технікою. 
Порадившись з кузеном Андрієм, мама головного героя вирішила віддати його до школи, а згодом до ремісника, хоча «... соромно для фермерської дитини займатися ремеслом і робити за нього будь-яку роботу» [2, с. 186]. Можливо, якби був живий батько і мати мала досить землі і не була би такою темною жінкою, Антек знайшов би своє місце i в рідному селі. Бо саме з смертю батька мати почала привчати Антека до роботи по господарству, але в нього не дуже добре виходило, так як весь час він був зайнятий струганням паличок. За це мати називала його виродком, бо «не буде з нього не те що господаря, а й наймита путнього, хіба дармоїд, на сміх людям і на гріх перед богом!» [2, с. 186]. Цієї ж думки притримувався і кум Анджей, вважаючи, що Антек господарем не стане, «бо на це в нього й розуму не стане» [2, с. 186].

Як видно, герої оповідань Б. Пруса стають сиротами, втрачаючи когось із батьків: чи то матір чи батька. Але життя з батьками не приносить їм очікуваного доброботу і вони змушені вирушати у великій світ, як Антек чи Валек, чи йти до школи, як Казек і Юзек. I лише втрата дітей призводить до того, що батьки відчувають свою провину перед ними і не знаходять собі місця після їх втрати (батько Юзека та мати Валека) і закликають повертатися, «якщо там, у чужих, буде погано» [2, с. 205].

Отже, тема дитинства і дитячого сирітства $\epsilon$ невичерпною, бо дитинство - не просто фізіологічний критерій періоду людського життя, а й універсальний літературний метод впливу на будь-які соціальнокультурні прошарки та морально-етичні цінності суспільства.

Соціальна проблема сирітства, яку у своїх творах висвітлює Б. Прус, $\epsilon$ досить актуальною і у сучасному суспільстві. Особливо прикро, що в нашій країні щороку збільшується кількість дітей-сиріт, дітей, які знаходяться на межі виживання. Варто пам'ятати, що кожна дитина повинна бути щасливою, вона має на це право. Утрата батьків для дитини страшна своїми наслідками: бідність, поневіряння, сум, відсутність перспектив подальшого щасливого життя. Виховання поза сімейним середовищем призводить до того, що відчуття сирітства супроводжує людину все життя.

\section{Література:}

1. Ковальська I. Образ дитини в малій прозі Б. Пруса та М. Коцюбинського. Волинь філологічна: текст і контекст. Польська, українська, білоруська та російська літератури в європейському контексті. Вип. 6. Ч. ІІ. С. 32-33.

2. Прус Б. Твори в 5-ти томах. Т. 2. Повісті. Оповідання. Київ, 1978. $495 \mathrm{c}$. 